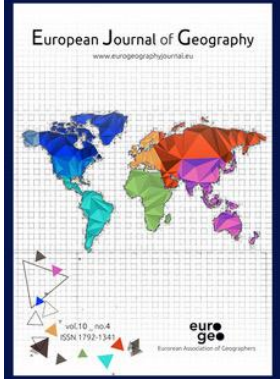

European Journal of Geography

Volume 11, Issue 1, pp. 140 - 162

Article Info:

Received: 20/09/2020; Accepted: 19/10/2020

Corresponding Author: *aznarulislam@gmail.com

https://doi.org/10.48088/ejg.a.isl.11.1.140.162

\title{
Assessing meander belt width of Bhagirathi-Jalangi river system in lower Ganga delta, India
}

\author{
Aznarul ISLAM $^{1^{*}}$, Balai Chandra DAS ${ }^{2}$ \\ Nishith Kumar MAJI3 , Suman Deb BARMAN ${ }^{4}$
}

\author{
${ }^{1}$ Aliah University, India \\ ${ }^{2}$ Krishnagar Gout. College, India \\ ${ }^{3}$ Kolkata Port Trust, India \\ ${ }^{4}$ The University of Burdwan, India
}

\section{Keywords: \\ meander belt width, normalized difference water index, pixel-based classification, palaeo-channels, factor of safety, fluvial architecture, hydraulics}

\begin{abstract}
The present work is an attempt to assess the meander belt width of the river Bhagirathi (frequently oscillating) and river Jalangi (relatively stable) in West Bengal, India based on geospatial data and field data (lithological composition and flow characteristics). Belt width has been computed using four major considerations in increasing order of scale- (i) individual loops of the present channel (MBw1), (ii) maximum loop width of the present channel (MBw2), (iii) palaeo channel characteristics identified through normalized difference water index and pixel-based classification coupled with field observation (MBw3) and (iv) future channel based on the factor of safety which is a space-time averaged safe belt width (MBw4). The study found MBw4 of $11.76 \mathrm{~km}$ for Bhagirathi and $6.64 \mathrm{~km}$ for Jalangi considering the 100-year factor of safety. The higher meander belt width of Bhagirathi in comparison to Jalangi was found to be correlated with higher monsoon discharge, bed slope, stream power, shear stress, suspended surface sediment concentration, D50, and lower relative bed stability.
\end{abstract}

The publication of the European Journal of Geography (EJG) is based on the European Association of Geographers' goal to make European Geography a worldwide reference and standard. Thus, the scope of the EJG is to publish original and innovative papers that will substantially improve, in a theoretical, conceptual or empirical way the quality of research, learning, teaching and applying geography, as well as in promoting the significance of geography as a discipline. Submissions are encouraged to have a European dimension. The European Journal of Geography is a peer-reviewed open access journal and is published quarterly. 


\section{INTRODUCTION}

Meander belt is an important part of meander geometry that portrays the hydrodynamics of a river. The study of meander geometry including belt width is an established field of inquiry in hydraulic sciences for a long (e.g. Inglis, 1947; Leopold and Wolman, 1960; Ferguson, 1976). Delineation of belt width is a major task before geomorphologists and hydraulic engineers for its landscape planning orientation (Biron et al, 2014) because since the inception of civilization man has settled in the proximity to the river for hydro and agro-ecological perspectives (Adedeji, 2011). River, on the one hand, blesses our civilization by its fertile land, freshwater, and environment and it paralyzes civilization by severe flood and bank erosion on the other (Sanyal and Lu, 2006). From this vulnerability perspective, protecting riverbank by various engineering methods has long been a key issue in traditional hazard management study (Smith, 2009). However, in the wake of the emergence of the hydro-ecological approach and environmental flow in recent decades (Brierley and Fryirs 2005; Roni and Beechie, 2012), the paradigm, has become more eco-friendly and believes in the minimum modification of river by engineering practices. This notion emphasizes the physical and ecological integrity of living, dynamic, and evolving aquatic ecosystems, with a focus on process-based restoration where the river can 'heal itself' (Beechie et al., 2010; Kondolf, 2011). Besides, the tell-tale marks of river instability and negative health impact of river induced by engineering practices can be minimized (Bravard et al., 1997; Brierley and Fryirs, 2004). Thus understating the negativities, the river corridor approach focusing on the channel oscillation by lateral migration, channel cut-off, and stream auulsion gained popularity over the last few decades. Quite naturally delineating river corridor or belt width has been attempted by some scholars. Bridge and Tye (2000) have determined the belt width of palaeo channels based on lithofacies analysis of wireline logs and cores. However, the delineation of meander belt width by the application of remote sensing coupled with field observation is commonly observed in recent studies. Cygnia and Timothy (2003) have computed channel migration zone based on historical migration zone, auulsion hazard zone, erosion hazard area, and disconnected migration area from field observation and satellite images. Biron et al. (2014) considered a risk (flood and erosion) and ecological integrity while delimiting belt width. Recently factor of safety has been taken into consideration for belt with delimitation (Ness, 2004). The previous works indicated that belt width delineation is not at all new and drawing attention from the scientists exponentially.

In Ganga-Brahmaputra (GB) delta, rivers especially the Bhagirathi-Hooghly system has been explored in terms of channel oscillation since long (e.g. Rennell, 1788; Sherwill,1858; Hirst,1915; Mukherjee, 1938; Bandyopadhyay,1996; Ray, 1999; Bhattacharya, 2000; Rudra, 2010) and meander behaviour (e.g. Basu, 1976; Basu et al., 2005; Guchhait et al., 2016; Islam and Guchhait, 2017a). The meander belt width of this active deltaic river channels has become a matter of serious concern as it is one of the most densely populated areas in the world. Human activities especially the intensive agricultural practices and the expansion of settlements are notable in West Bengal (Shit, Bhunia, and Maiti, 2015; Halder, 2018) which are more conspicuous within the meander belt. That is why the counter effect between human activities and river channel oscillation in the meander belt often causes the long-lasting problem to both rivers and in turn to the human being. Besides, river training and controlled river regime may keep civilization in a safer place up to a certain extent. But the complexity 
in geomorphic evolution often makes costly training works futile in the long run (Chitale, 2000). So, what is essential is to perceive river behavior in place of river control (Mazumder, 1993; Mazumder, 2004; Rudra, 2011). However, most of the previous works missed the approach to deal with the meander belt width. Thus, it would be a novel attempt to address those gaps through the following objectives.

1. To delimit belt width of Bhagirathi and Jalangi from the consideration of present, past, and future channel characteristics, and

2. To assess dynamism in belt width from the hydro-geomorphological perspectives especially with regard to fluvial architecture and hydraulics.

\section{MATERIALS AND METHODS}

\subsection{Geomorphic set up of the study area}

The Ganga-Brahmaputra delta is the largest delta of the world with a subaerial surface area of $110,000 \mathrm{~km}^{2}$ (Bandyopadhyay, 2007). River Ganga a major component in this deltaic system is, at present, greatly controlled by the Farakka Barrage Project (FBP) in its upper and lower stretches (Mandal, 2017). So, the landscape evolution and the channel instability of this tract are the results of the hydrologic alteration from FBP in the lean period and the monsoon regime in the freshet (Islam and Guchhait, 2017b). The present investigation is concentrated in the lower stretch of the Bhagirathi River, an offshoot of the Ganga flowing through the state of West Bengal, India to make an outfall into the Bay of Bengal. In this stretch, Lower Bhagirathi and Lower Jalangi have been selected to study the dynamics of the meander belt width. Lower Bhagirathi extends from Ajay-Bhagirathi confluence at Katwa to the Jalangi-Bhagirathi confluence at Nabadwip while lower Jalangi extends from the Saraswati-Jalangi confluence at Malipota to Jalangi-Bhagirathi Confluence at Nabadwip (Figure 1). Thus the three confluence points constitute a triangular area having an extension from $23^{\circ} 39^{\prime} 22^{\prime \prime} \mathrm{N}$ to $23^{\circ} 24^{\prime} 40^{\prime \prime} \mathrm{N}$ and from $88^{\circ} 08^{\prime} 14^{\prime \prime} \mathrm{E}$ to $88^{\circ} 31^{\prime} \mathrm{O2}$ " $\mathrm{E}$ (Figure 1). In this area, the Bhagirathi is roaming over the region extending from the lateritic belt at the western margin and up to the river Jalangi in the east which is very clear from the palaeochannels of Bhagirathi (Guchhait et al., 2016). But river Jalangi once an active channel is now virtually dead because it is presently disconnected from the Padma. Thus, it receives negligible flow from the upstream, especially in the lean months.

\subsection{Database}

The study is based on geospatial data and field data. For delineation of belt width Landsat 5 Thematic Mapper (TM) for 1990 and 2004 and Landsat 8 Operational Land Imager (OLI) for 2014 have been taken into consideration for the study area (Row- 138, Path-44). Besides, we collected four lithologs on the right bank of Bhagirathi River, two on the left bank of the Jalangi River and three in the Bhagirathi-Jalangi interfluve from the office of State Water Investigation Directorate (SWID), Gout. of West Bengal. We also collected daily velocity and discharge data measured by Central Water Commission (CWC) during 2005-2010 at Katwa, and Swarupganj for the Bhagirathi River and at Mayapur for the Jalangi River. Besides, channel depth, bed slope, sediment 
concentration and D50 data for both rivers have been gathered from Kolkata Port Trust (KoPT) during 2009-2010. Besides, we also collected data on bank material composition from the extensive field investigation during 2014-2018.
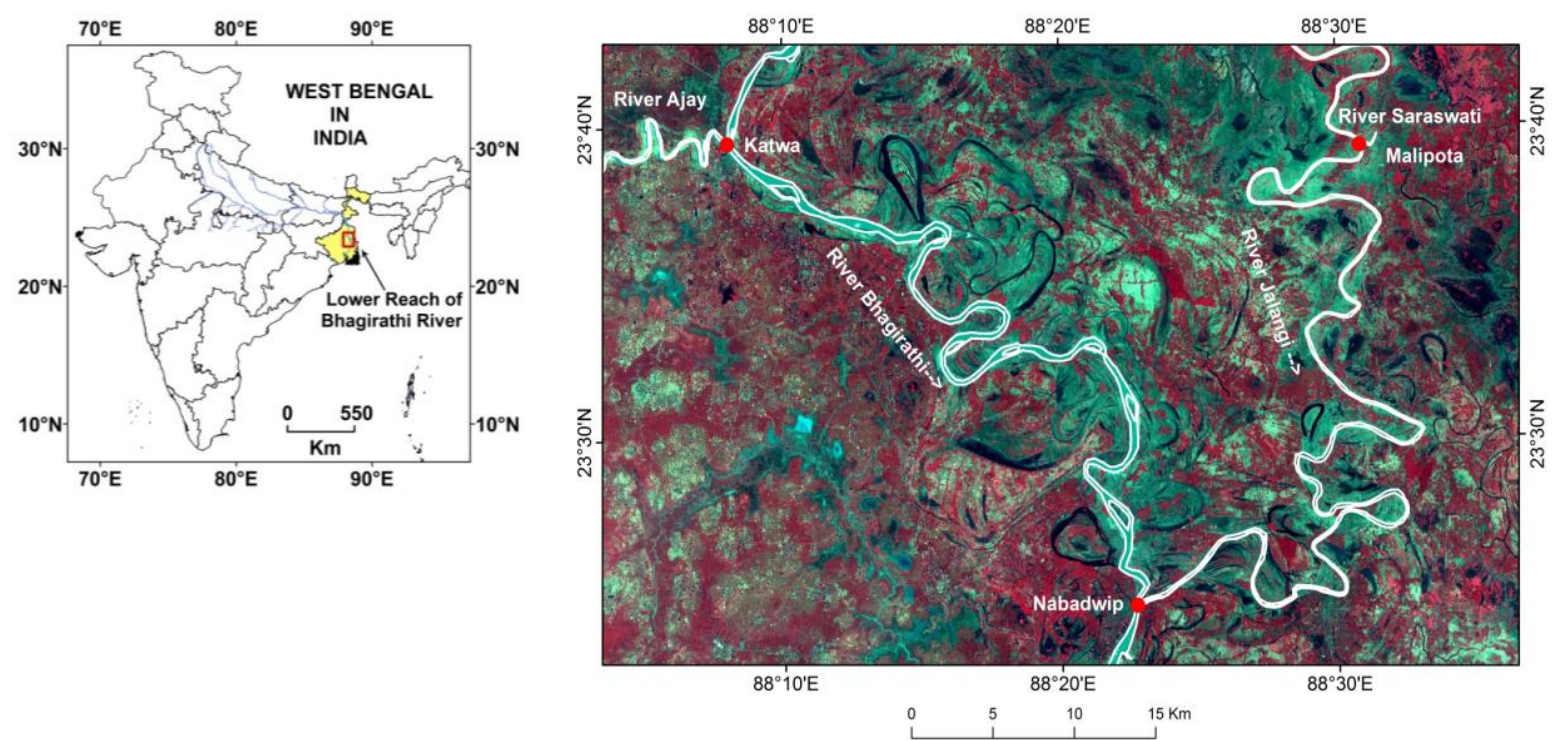

Figure 1. Location of the study area

\subsection{Methodology}

\subsubsection{Meander belt with delineation}

We addressed the problem of delineation of meander belt width following systematic methodological steps as below.

\section{a. Selection of loops}

The loops having the sinuosity index above 1.05 have been taken into consideration for the study of meander belt width. For Bhagirathi a total of 12 loops ( 6 on each bank) for 1990; 11 loops ( 6 on left bank and rest on the right bank) for 2004 and another 11 (5 on left bank and the rest on right) have been selected while a total of 18 loops (9 on each bank) have been considered for Jalangi river for 1990, 2004 and 2014 (Figure 2 a, b).

To delineate meander belt width, basic meander geometry parameters like amplitude $\left(a_{m}\right)$ and channel width $(w)$ have been computed from the images with the help of the measurement tool of ArcGIS 9.2. The present analysis is based on buffering which has been done using the buffer tool of ArcGIS

b. Defining MB Axis and channel axis

Before we enter into the actual delineation of the meander belt width, it is essential to define the meander belt axis. Various scholars have defined axis in their ways. Along a meander axis, the sum of all the directional changes is zero, and variance (mean square of deviations in direction) is minimum (Langbein and Leopold, 1966). The rectilinear meander axis is the centerline of the meandering pattern downstream of the valley slope (Julien, 1985). In the present study, the MB axis has been assumed to be a line to divide the individual meander belt into two halves into the opposite sides. In this 
delineation, the first peak of the individual loop has been joined by a straight line on both sides of the channel. Then using the ArcGIS tool 'collapse dual-line' a centerline has been drawn. Finally, the MB axis has been smoothened by ArcGIS 'smooth line' tool. This smooth line constitutes the $\mathrm{MB}$ axis for the delineation of the meander belt of different orders discussed in the following section.
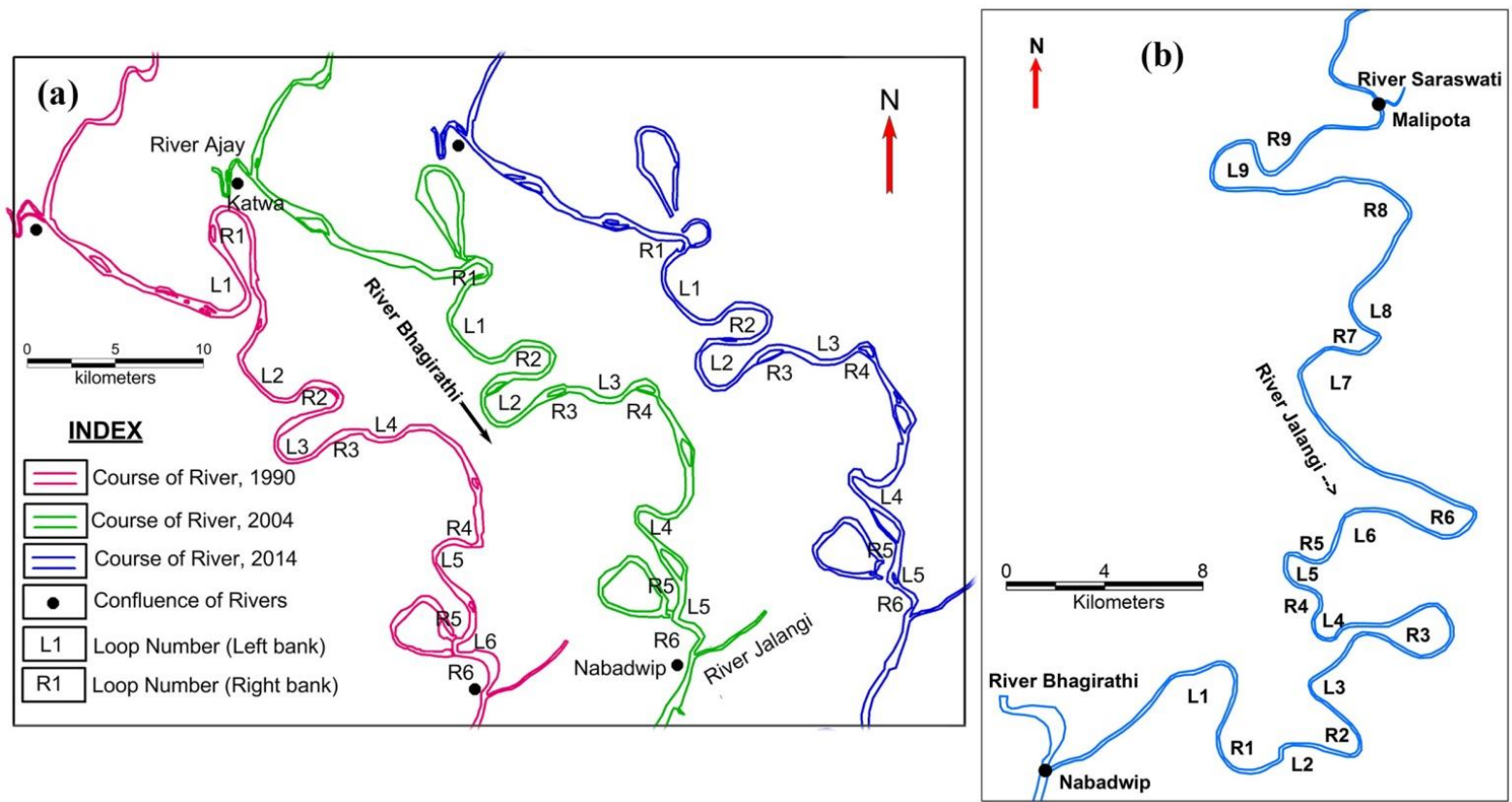

Figure 2. Location of the selected meander loops; (a) Bhagirathi river $(1990,2004,2014)$ (b) Jalangi River $(1990,2004,2014)$

For defining channel axis (centerline) from satellite images Normalized Difference Water Index (NDWI) has been computed after Mcfeeters (1996) in the following way.

$$
\text { NDWI }=\frac{X g r e e n-X \text { nir }}{X \text { green }+X \text { nir }}(\mathrm{i})
$$

This method is capable of detecting changes in water content in water bodies. The pixels recording NDWI value as zero are defining the channel boundary. The pixels having positive values are denoting water bodies whiles the negative ones indicating other features. After defining the channel boundary, transects of endpoints have been drawn across the entire reach the simple arithmetic average of which gives the channel centerline or the channel axis (Magdalenoand Fernández-Yuste, 2011).

\section{c. Delineating palaeo channels}

Delineating the palaeo channels is a major problem before the geomorphologists. Observing the inefficiency of traditional water indices (NDWI- Gao, 1996; McFeeters, 1996) to delimit the active and the palaeo channels of the river as constrained by the growth of aquatic plants (algae and water hyacinth), the pixel value of a particular band (SWIR in place of either band ratio or false colour composites (FCCs) have been considered for the present case. To attempt that task using mono-spectral images (SWIR band), we used a pixel-based classification. An image consists of pixels having unique DN value aiding delimitation of palaeo-channels. For the present study, three different images have their different radiometric scales $-2^{8}(0-255)$ for 1990 and 2004 
while $2^{16}(0-65,535)$ for the 2014 image but the grayscale present in the actual scene ranges from 1-212 for 1990, 1-255 for 2004, and 5479-64732 for 2014. The 'limiting pixels' defining channel boundary have DN 22, 30, and 8000 for 1990, 2004, and 2014 respectively. So, the channels comprised of the pixels having DN less than equal to limiting pixels have been extracted through a binary classification ( 1 for channel and 0 for other features). Now the channels which are currently active are excluded by NDWI values and field verification and the remaining channels are classified as palaeo. To validate the pixel-based classification a total of 527 pixels have been selected from the image. At the first stage the pixels were classified as land pixel $(\mathrm{N}=297)$, water pixel $(\mathrm{N}=183)$, and hybrid pixel-containing a varying proportion of both the land and water $(\mathrm{N}=46)$. At the second stage, hybrid pixels were reclassified as either land $(\mathrm{N}=21)$ or water $(\mathrm{N}=25)$ pixels based on their relative proportion. Thus finally we derived 318 land pixels and 208 water pixels which were converted into point data to get its centroid location on the ground. With the help of GPS, we tracked the exact pixel location followed by the ground extrapolation of that pixel having $30 \mathrm{~m}$ dimension from its centroid. In the end, we run a correlation between image-derived binary and ground derived binary of that 527 sample pixels which depict a near-perfect correlation ( $r=$ 0.97).

\section{d. Techniques for delimiting meander belt width}

Delineating meander belt is not a serious problem for regular and simple meanders but it is not so easy for the irregular and compound meanders (VTANR, 2004). There are various methods for delimiting the width of the complex meander belt as discussed by Ness (2004). Bhagirathi and Jalangi rivers of Bengal delta exhibit exquisite examples of the irregular meander. Therefore, to delineate their belt widths four techniques (modified after Ness, 2004) have been applied to unveil the complexity of the meander pattern. They are as follows:

$$
\begin{aligned}
\text { i. } & M B_{w 1}=2 a_{m}+w \text { (ii) } \\
\text { ii. } & M B_{w 2}=2 d a+w \text { (iii) } \\
\text { iii. } & M B_{w 3}=2 d P+w \text { (iv) } \\
\text { iv. } & M B_{w 4}=\left(2 a_{m}+w\right) * F S+M_{a x} 100 .(u)
\end{aligned}
$$

Where $\mathrm{MB}_{w}$ Meander belt width; da=distance of the farthest point of the present channels from meander axis; $\mathrm{dP}=$ distance of the farthest point of the palaeo channels from meander axis; FS=Factor of safety $=1+\left(\mathrm{m}_{100} / M B_{w_{-} \max }\right), \mathrm{m}_{100}=$ distance of migration or absolute shift of Channel centre line in 100 years, $M B_{w_{-} \text {max }}$ for maximum belt width of the present channel, $M_{a \times 100}=$ migration or absolute shift of meander axis in 100 years.

\section{e. Share of overlapped meander belt between two confluence rivers}

Generally, it is found that all variables of meander plan forms are dependent on channel width (Knighton, 1977) and streams width varies as the square root of discharge. Thus, since discharge increases with distance from the source, the width will increase in the downstream direction and meander dimensions will vary accordingly' (Knighton, 1977). So it is very much supported by the width dependent nature of planform geometry of a meandering river. And the magnitude of the channel width of two rivers can be used for delimiting the boundary between meander belts of two rivers where they confluence and have an overlapped zone of common meander belt.

Share of overlapped meander belt width by channel $C_{1}$ with average channel width $\omega_{1}$ can be delineated using formula. 


$$
\frac{w_{1}}{w_{1}+w_{2}} \times \mathrm{Mb}_{0} \text { (vi) }
$$

Where $w_{1}$ and $w_{2}$ are average widths of channel $c_{1}$ and $c_{2}$ respectively. $M b_{0}$ is the width of the overlapped meander zone of two channels measured along lines drawn perpendicular to the line connecting the point of the junction at the confluence and the point of the intersection of lines delineating meander belt width of two rivers.

\subsubsection{Measuring discharge using $A D C P$}

Hydrological observations for velocity and discharge measurement in the river are conducted at three locations namely at Katwa, downstream of Jalangi river at Swarupganj, and in the confluence of river Jalangi deploying the state of Art equipment Acoustic Doppler Current Profiler (ADCP) mounted on the bottom of the ship's outer hull using the principle of "Doppler shift". The ADCP having 4 acoustic transducers that emit and receive acoustical pulses from 4 different directions used a lower frequency $(75 \mathrm{kHz}$ ) to reach as deep as $700 \mathrm{~m}$ of Bhagirathi river. An on-board computer processes the returned signal and a real-time display of the magnitude and direction of the current throughout the water column is produced on the computer monitor.

\subsubsection{Sediment analysis (sediment concentration and grain size distribution)}

The samples collected from the bed and the surface were analyzed in the following steps in the laboratory to determine sediment concentration. First, the one-liter water sample from the surface and near the bed is collected from the desired location. Secondly, the suspended material is separated by filtration using a known weighted filter paper. Third, filter paper with the sample is weighted (Total weight). Finally, after substruction of the weight of the filter paper from the total weight, we get the sediment concentration in $\mathrm{gm} /$ lit.

A Sieve shaker machine is used for identifying the different sizes of particles present in the sample. A simplistic definition of sieving is the separation of fine material from coarse material employing a meshed or perforated pot by vertical movement (uibratory sieving) or horizontal motion (horizontal sieving). Steps adopted for determining grainsize distributions (D50) using a sieve shaker are as follows.

i. The soil sample is dried in an oven and kept in desiccators.

ii. $100 \mathrm{gms}$ of dried sample is taken.

iii. The dried sample then is placed in the sieve set containing sieves of mesh nos.B.S. 36 (dia. $-0.425 \mathrm{~mm}$ ), 52(dia. $-0.300 \mathrm{~mm}$ ), 60 (dia.- $0.250 \mathrm{~mm}$ ), 72 (dia. -0.212 $\mathrm{mm}$ ),100(dia. $-0.150 \mathrm{~mm}$ ),120(dia. $-0.125 \mathrm{~mm}$ ), 150 (dia. $-0.106 \mathrm{~mm}$ ), 170 (dia. -0.090 $\mathrm{mm}$ ),200(dia.-0.075 mm),240(dia.-0.063 mm),300(dia.-0.053 mm),350(dia.$0.045 \mathrm{~mm}$ ) \& 400 (dia. $-0.038 \mathrm{~mm}$ ) arranged in descending order of coarseness which is shaken by electrically operated sieve shaker for 5-6 minutes after which the residues in each sieve are weighed \& recorded and finer percentage of each sieve in gram are calculated.

iv. A grain distribution curve is then plotted with the finer percentage against each said sieve diameter in $\mathrm{mm}$ in semi-log graph paper. The finer percentage is taken in the vertical axis and said sieve diameter in $\mathrm{mm}$ is taken along the horizontal axis. 
v. Finally, we get an S-curve from where we can calculate the finer percentage of grain size distribution having all diameters such as diameter do $_{10}$ tiameter ${ }_{90}$, mean diameter, and uniformity coefficient.

\subsubsection{Computation of stream power and shear stress}

Stream power determines the ability of a stream to erode and transport through its channel. Stream power $(\Omega)$ and shear stress $(\tau)$ have been computed using the following algorithm.

$$
\begin{aligned}
& \Omega=\rho g \mathrm{~g} S \text { (vii) } \\
& \tau=\rho \mathrm{ghS} \text { (uiii) }
\end{aligned}
$$

Where $\rho=$ water density i.e. $1000 \mathrm{~kg} / \mathrm{m}^{3} ; \mathrm{g}=$ acceleration due to gravitational force i.e. 9.81; $Q$ = discharge and $S=$ channel slope i.e. $\mathrm{m} / \mathrm{m} ; \mathrm{h}=$ flow depth $(\mathrm{m})$

\subsubsection{Relative bed stability analysis}

It is rational to assume that the higher the channel instability wider is the channel oscillation belt or meander belt. The present section applied the methodology of finding relative bed stability (RBS) to find out the channel stability (Olsen et al, 1997). Relative bed stability (RBS) is the ratio of the critical condition of the existing condition during bankfull discharge (Jowett, 1989; Gordon et al., 1992)). It may be the ratios between shear stresses, discharges and velocities of critical value to bankfull value. Here we adopted the ratio of critical velocity for entrainment of $D_{84}$ particle (critical sediment size for bed stability) to bankfull bed velocity (Olsen et al, 1997).

$$
R B S=\frac{V_{c}}{V_{b}} \quad \text { (ix) }
$$

Where $V_{c}$ is critical velocity and $V_{b}$ the bankfull velocity

If RBS is $\mathbf{1 . 0}$ the bed is at a critical position. Higher the value the bed is more stable and vice versa.

\section{RESULTS}

\subsection{Belt width on the consideration of present channel geometry}

Meander belt $1\left(\mathrm{MB}_{w 1}\right)$ for both Bhagirathi and Jalangi in lower reach has been computed according to the above-mentioned technique for three different periods viz. 1990, 2004, and 2014. The belt width of Bhagirathi is more variable than that of Jalangi. In 1990 the average belt width of Bhagirathi has recorded $3.62 \mathrm{~km}$ whereas it was 2.91 $\mathrm{km}$ for Jalangi (Figure $3 \mathrm{a}, \mathrm{b}$ ). But this hiatus came to decrease in 2004 due to a major meander cut off of river Bhagirathi i.e. Bishnpur-Char Chakundi $1^{\text {st }}$ cut-off that took place in 1994 reducing river length by $11 \mathrm{~km}$ (Islam, 2016). In 2004 belt width of Bhagirathi coincides with that of Jalangi with a value of $2.9 \mathrm{~km}$. In 2014 belt width of river Bhagirathi falls below that of Jalangi due to another cut-off i.e. Bishnupur- Char Chakundi $2^{\text {nd }}$ cut-off that occurred in 2008 reducing river length by $3.6 \mathrm{~km}$.

Meander belt $2\left(\mathrm{MB}_{\mathrm{w2}}\right)$ has been delimited for both the Bhagirathi and Jalangi river for the years 1990, 2004, and 2014. The value of $M B_{w 2}$ for Bhagirathi is decreasing with time. The buffer of $\mathrm{MB}_{\mathrm{w2}}$ has come down to $5.7 \mathrm{~km}$ in 2014 from the value of $8.64 \mathrm{~km}$ of 1990. This gradual reduction may be due to the gradual channel straightening by cut- 
off as mentioned above. For Jalangi the $\mathrm{MB}_{w 2}$ is almost constant with the time which implies that Jalangi is virtually a dead river. But the higher belt width of Jalangi in 2004 and 2014 is a symptom of higher discharge flown through Jalangi very recently. It can be mentioned here that during the $18^{\text {th }}$-century Jalangi river regime was compared to Bhagirathi or even higher than Bhagirathi (Das, 2013). By eastward tilting of the Bengal basin, Jalangi has been virtually an inactive channel throughout the year except during the freshet period (Sen, 2010). In this delineation, overlapping zones of two rivers have been detected. By applying the methodology (equation 6 ) it has been observed that around $77 \%$ share of the overlapped area goes to Bhagirathi (Table 2).

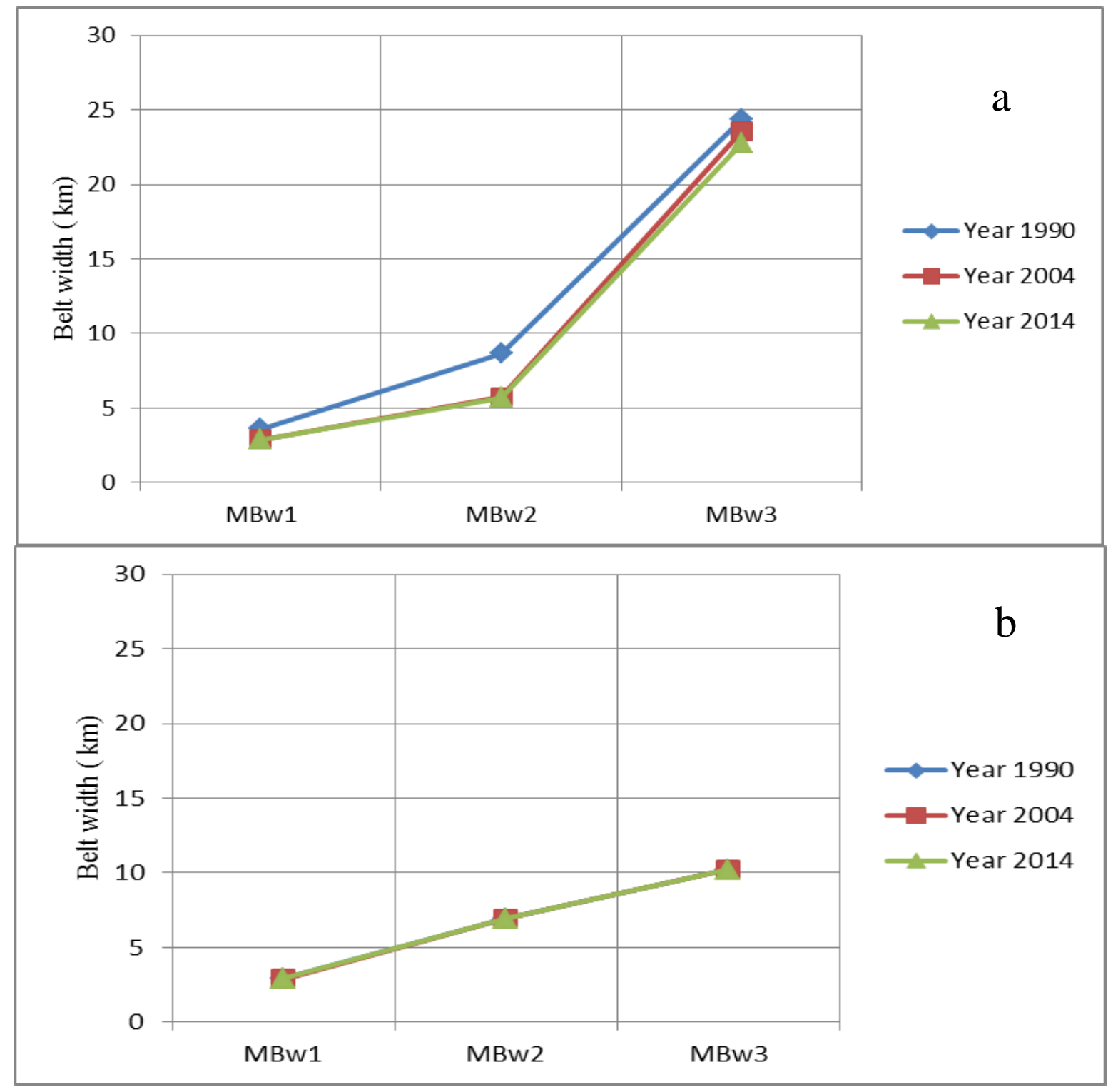

Figure 3. Meander belt width of a. Bhagirathi and b. Janalgi during 1990-2014

\subsection{Belt width on the consideration of past channel geometry}

For this delineation, the palaeo-channel of the Bhagirathi and Jalangi has been differentiated based on NDWI, pixel-based classification, and field verification and belt 
width has been determined accordingly. Based on the palaeo channel study belt width $\left(\mathrm{MB}_{w 3}\right)$ thus derived for Bhagirathi and Jalangi is $24.4 \mathrm{~km}$ and $10.2 \mathrm{~km}$ respectively for the year 1990(Figure $3 \mathrm{a}, \mathrm{b}$ ). With the time there is a gradual fall in the belt width for Bhagirathi due to channel cut-off but Jalangi occupies its original position because it's now a virtually dead channel. This delineates a maximum belt width along with its maximum overlapping. The problem of overlapping has been resolved with the abovementioned methodology based mainly on average channel width. Like belt width 2 $\left(\mathrm{MB}_{w 2}\right), \mathrm{MB}_{w 3}$ has a predominant share for the Bhagirathi due to its higher channel width (Table 1).

Table 1. Share of overlapped area

\begin{tabular}{|l|r|r|r|r|r|r|r|}
\hline & \multicolumn{3}{|c|}{ MBw2 } & \multicolumn{3}{c|}{ MBw3 } & MBw4 \\
\hline Year & 1990 & 2004 & 2014 & 1990 & 2004 & 2014 & 2014 \\
\hline Total & 13.75 & 9.18 & 8.89 & 65.82 & 84.48 & 76.93 & 17.7 \\
\hline Share of Bhagirathi $\left(\mathrm{km}^{2}\right)$ & 10.6 & 7.02 & 6.85 & 50.77 & 65.16 & 59.77 & 13.68 \\
\hline Share of Jalangi $\left(\mathrm{km}^{2}\right)$ & 3.14 & 2.16 & 2.04 & 15.05 & 19.32 & 17.16 & 4.02 \\
\hline Share of Bhagirathi (\%) & 77.09 & 76.47 & 77.05 & 77.13 & 77.13 & 77.69 & 77.29 \\
\hline Share of Jalangi (\%) & 22.84 & 23.53 & 22.95 & 22.87 & 22.87 & 22.31 & 22.71 \\
\hline
\end{tabular}

Source: Computed by the authors, 2016

\subsection{Belt width on the consideration of future channel characteristics}

This delimitation is based on the factor of safety in the future. It takes the consideration of the migration rate of channel and migration rate of the meander belt axis of 100 years. Here migration rate has been computed from the last 24-year shifting data which has been arithmetically projected into 100-year.

First channel migration of three periods viz. 1990, 2004, and 2014 have been depicted on superimposition (Figure 4a). From the superimposition of channel median lines, it has been observed that Bhagirathi has shifted on an average of $224 \mathrm{~m}$ from 1990 to 2004 with an annual average of $16 \mathrm{~m}$. Similarly, from 2004 to 2014 channel of Bhagirathi has shifted on an average $115 \mathrm{~m}$ with an annual average of $11.5 \mathrm{~m}$. Based on the above observations of the 24 years, the simple arithmetic projection confers the shifting value of this channel $1381 \mathrm{~m}$ for the 100 years while Jalangi remains standstill in its position with time. Secondly, to compute the migration of the meander belt axis, three axes positions of 1990, 2004, and 2014 have been superimposed (Figure4b). This portrays that Bhagirathi has shifted $737 \mathrm{~m}$ from 1990 to 2004 with an annual average of 52.64 $\mathrm{m}$ while the river under consideration has shifted $294 \mathrm{~m}$ during 2004-2014 with an annual average of $29.4 \mathrm{~m}$. Based on the 24-year observation period, an arithmetic projection has been accomplished to get the 100-year average. The average value of shifting for a century is $\mathbf{4 1 . 0 2} \mathrm{m}$ per year for river Bhagirathi while Jalangi has shown a definite trend of stand stillness in its position with time or virtual stability of the channel which is indicated by the NDWI. 


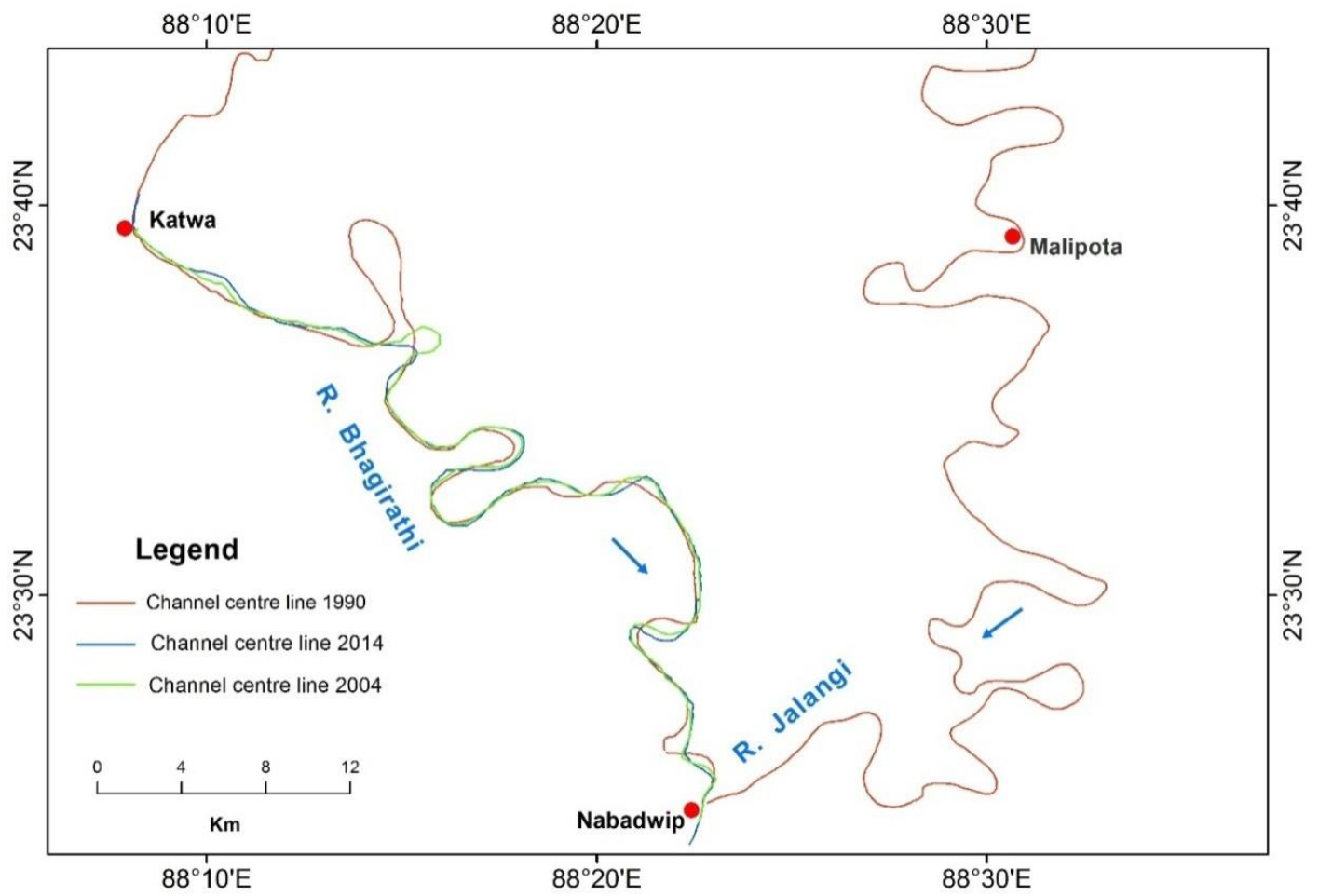

Figure 4a. Shifting of channel center line during 1990-2014

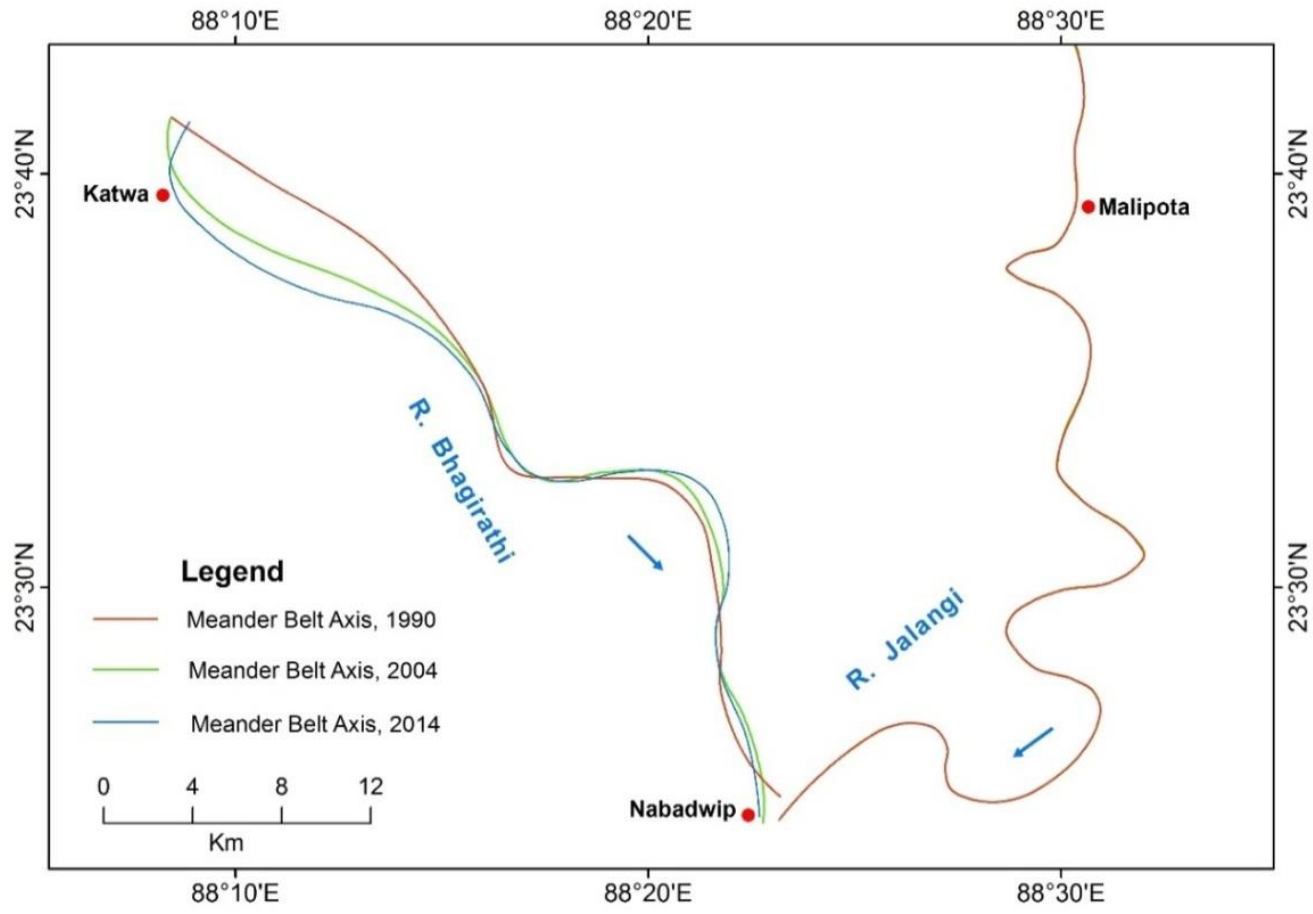

Figure 4b. Shifting of meander belt axis during 1900-2014

Based on the 100-year average migration rate of belt axis and channel centerline, the factor of safety derived thereof are 1.2 and 1 for Bhagirathi and Jalangi respectively. 
Hence final belt widths from the factor of safety consideration are about $11.8 \mathrm{~km}$ and $6.6 \mathrm{~km}$ respectively (Table 2 and Figure 5). This belt width may be treated as the active freedom space of the rivers which may be used in planning purposes.

Table 2. Computation of factor of safety

\begin{tabular}{|l|r|r|}
\hline & Bhagirathi & Jalangi \\
\hline Migration of channel axis, 100-year average $(\mathrm{m})$ & 1381.14 & 0 \\
\hline Migration of MB axis, 100-year average $(\mathrm{m})$ & 4102 & 0 \\
\hline Belt width of the present channel $(\mathrm{m})$ & 5920 & 6560 \\
\hline Factor of Safety & 1.233301 & 1 \\
\hline Mean Channel width $(\mathrm{m})$ & 290 & 80 \\
\hline Final belt width (m) & 11760.8 & 6640 \\
\hline
\end{tabular}

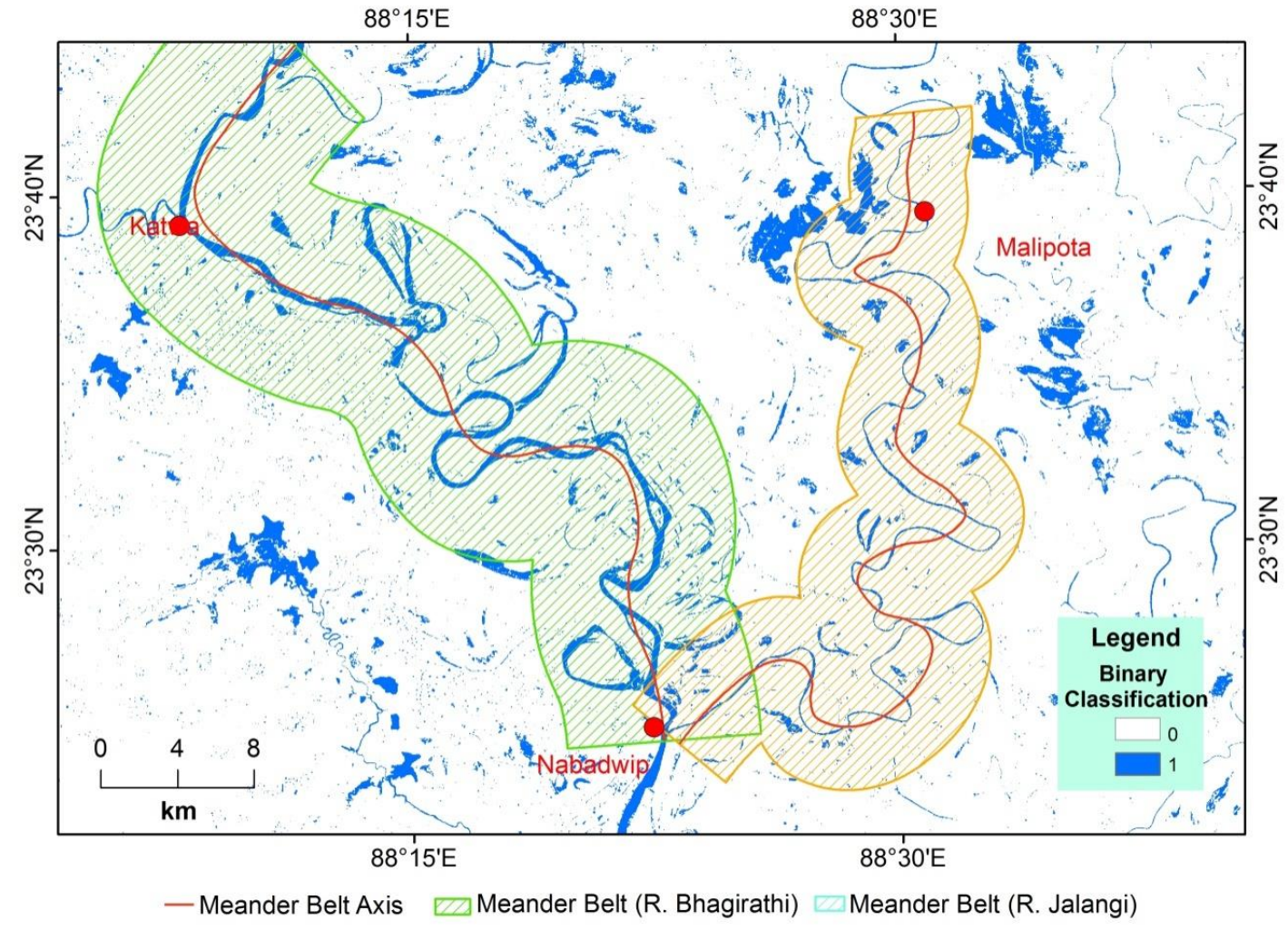

Figure 5. Delineation of meander belt width based on the factor of safety

\section{DISCUSSION}

Belt width is principally controlled by two factors- bank material composition and fluvial hydro-dynamics.

\subsection{Bank material composition and fluvial architecture}

The fluvial architecture was analyzed to relate the composition and succession of 
various sediment layers to susceptibility to fluvial erosion. We went through four lithostratigraphic units (BH 1-Islampur, BH 2-Chakbahara, $\mathrm{BH}$ 3- Madhupur, and $\mathrm{BH}$ 4Singhari) on the right-bank floodplain of the Bhagirathi-Hooghly river, three (BH 5Narayanpur, BH 6- Dolimoula and BH 7- Tatla) in the Bhagirathi-Jalangi interfluve and another two (BH 8-Mahatpur and $\mathrm{BH}$ 9- Panshila) on the left bank of the Jalangi river (Figure6a)

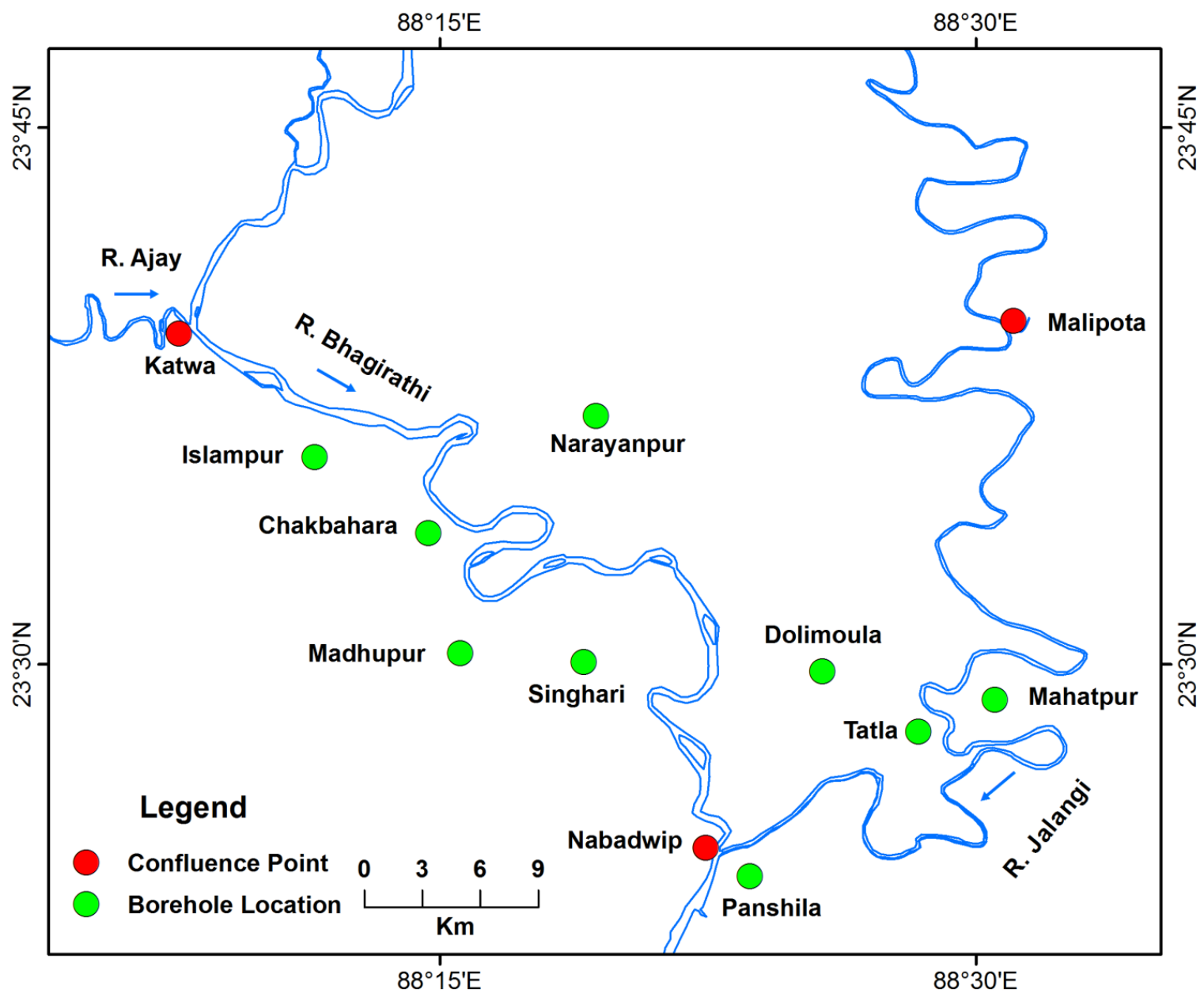

Figure 6a. Location of boreholes

The litho-facies in the right-bank floodplain of the Bhagirathi-Hooghly system are dominated by clay. Borehole at Islampur (BH 1) shows fine-grained facies mainly ' $\mathrm{Fl}$ ' (laminated sand, silt, and mud deposited on the overbank of Bhagirathi from the suspension and weak traction current) and 'Fm' (massive mud and silt formed by low stage channel abandonment) in alternating layers up to a depth of $55 \mathrm{~m}$ from the surface underlain by a thin sand facies-'Sh' (horizontally bedded sand formed at subcritical to supercritical flow, Miall 2006) from $55 \mathrm{~m}$ to $60 \mathrm{~m}$. Similarly, BH 2 at Chakbahara depicts clay facies (Fl, and Fm) up to a depth of $\sim 44 \mathrm{~m}$ from the surface underlain by the sand facies - 'Sr' (ripple cross-laminated sand formed at flow speed less than $1 \mathrm{~m}^{-\mathrm{s}}$, Miall 2006)and 'St' ( trough cross-bedded sand formed due to migration of 3D dune) at the depth from $44 \mathrm{~m}$ to $85 \mathrm{~m}$. and the bottom set of the $\mathrm{BH} 2$ is constituted by the fine-grained facies $(\mathrm{Fl})$ at the depth of 84-90 m. Lithofacies at Madhupur ( $\mathrm{BH} \mathrm{3}$ ) is dominated by clay ( Fl, Fm) but the sand facies 'Sr' and ' $\mathrm{Sh}$ ' are 
juxtaposed in between clay facies at the depth of $9 \mathrm{~m}$ to $15 \mathrm{~m}, 18.5-21 \mathrm{~m}$, and $45-52 \mathrm{~m}$. Again, borehole at Singarai ( $\mathrm{BH} 4$ ) shows the dominance of clay facies (Fl, Fm) underlain by the few sand facies- 'Sr', 'St' and 'Ss' or scour-filled sand formed by the rapid deposition of unsorted coarse bed load, Miall 1977) at the depth of 33-41 m, 45-51 $m$, 57-94 m (Figure 6b).

The facies at the interfluve region and left-bank flood plain of the Jalangi river depict similar characteristics i.e. facies dominated by sand instead of clay as on the right bank of Bhagirathi-Hooghly river (Guchhait et al., 2016). The BH 5 at Narayanpur shows fine-grained facies- Fl, Fm, only up to $60 \mathrm{~m}$ from the surface beyond which sand facies ( $\mathrm{Sh}, \mathrm{St}$, and $\mathrm{Sr}$ ) dominate up to $130 \mathrm{~m}$ which clearly shows an upward fining sequence. Facies at Dolimoula $(\mathrm{BH} 6)$ and Tatla $(\mathrm{BH} 7)$ portray similarity with the $\mathrm{BH} 5$ regarding facies sequencing. The surface layers are dominated by clay facies (Fl, Fm) up to $20 \mathrm{~m}$ for BH 6 and $45 \mathrm{~m}$ for BH 7. Beyond this limit, sand facies - Sr, St, Sh, Sp ( planar crossbedded sand formed by the migration of 2D dunes) and $\mathrm{Sm}$ (massive sand having a sand stone bed in outcrop ) dominates up to $120 \mathrm{~m}$. One distinguishing feature of $\mathrm{BH} 6$ and $\mathrm{BH} 7$ is the dominant presence of grey and yellow color facies which signifies the generation of facies in the reducing environment or a saturated state. Similar to the interfluve facies, the left bank facies portrays surface set clay concentration ( $\mathrm{Fl}, \mathrm{Fm}$ ) up to $26 \mathrm{~m}$ in the case of BH 8 at Mahapur and $60 \mathrm{~m}$ for Panshila. Beyond this limit, sand facies ( Sr, Sh, St, Sp, Sm) characterizes the litholog up to 130m ( Figure 6b).

The above description indicates that the cohesive hard clay on the right bank restricts the channel wandering to a certain limit at the western margin of the GB delta while the interfluve and the left bank facies are dominated by cohesionless sand having a high degree of detachability. Bhagirathi River is greatly controlled by lithofacies composition, especially on its right bank. But due to homogenous litho-stratigraphy on either side of the Jalangi river, it is free to meander equally on both sides. Despite this architectural favour to move, its meander belt width is lesser and more importantly stable thereby implying meander behaviour is more controlled by the fluvial hydraulics rather than the sub-surface architectural elements.

\subsection{Role of fluvial hydraulics}

River discharge has two major components- solid (sediments) and liquid (water). Channel instability is induced by the quantity of water and quantity and type of sediment flowing through the channel (Schumm, 1969). According to Lane's equation of balance (1955), channel aggradation or degradation will initiate depending upon the relative weights of sediments and water. Sediments in the form of total suspended or bedload and their size distribution (D50) induces the nature and extent of channel instability while water in terms of flow characteristics and the bed slope induces channel instability.

Discharge of water controls channel incision through a flood or peak discharge (high magnitude low-frequency event) and a full range of flow or average discharge (high-frequency low magnitude events). From 2005 to 2010, annual peak discharge ranged from $\sim 6770$ cumecs to $\sim 2110$ for Bhagirathi at Katwa while for Jalangi (Mayapur) it was from $\sim 480$ cumecs to $\sim 200$ cumecs. Concerning the annual average 


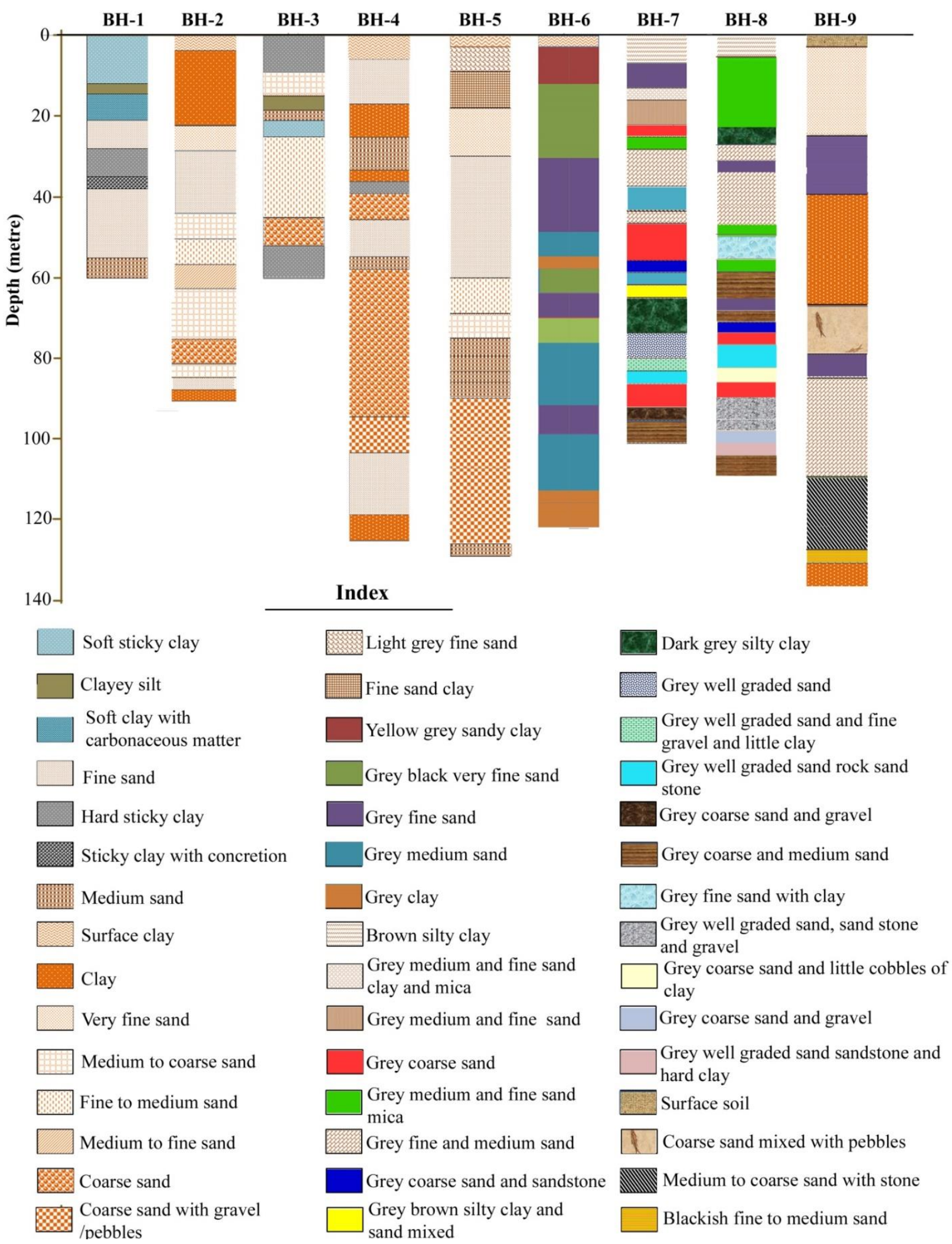

Figure 6b. Litho-stratigraphic composition at the selected boreholes 
discharge during 2005-2010, river Bhagirathi registers much higher volume ( 2125 Cumec from August to October and 1440 Cumec from January to December) that of Jalangi River ( 220 Cumec during August to October and $\sim 60$ Cumec during January to December) which has created huge oscillation of Bhagirathi. According to $\mathrm{Hu}$ et al., (2017), the peak to mean discharge ratio is important to determine the magnitude of instability. The higher the ratio, the greater the channel instability. The ratio computed for the active flow period (mid-July to October 2005-2010) is low ( 1.5) for the Jalangi River compared to Bhagirathi $(\sim 2)$. The stream power increases due to the increase of this ratio along with the increase in channel bed slope. From August to October (2001 to 2006), we observed the bed slope $\left(\mathrm{S}_{0}\right)$ of Jalangi in the Malipota-Nabadwip stretch $\left(\mathrm{S}_{0}=\right.$ 0.000023 ) comparatively gentler to that of river Bhagirathi in the Katwa-Nabadwip stretch $\left(\mathrm{S}_{\mathrm{o}}=\mathbf{0 . 0 0 0 1 3}\right)$. Higher bed slope coupled with the higher discharge, the stream power $(\Omega)$ in the same space-time sequence becomes greater for Bhagirathi $(\Omega=\sim 2780$ $\mathrm{W} \mathrm{m} \mathrm{m}^{-1}$ and $\Omega / \omega=\sim 8 \mathrm{~W} \mathrm{~m}^{-2}$ ) than Jalangi $\left(\Omega=\sim 50 \mathrm{~W} \mathrm{~m}^{-1}\right.$ and $\Omega / \omega=\sim 0.33 \mathrm{~W} \mathrm{~m}^{-2}$ ). Besides, the shear stress $(\tau)$ of Bhagirathi is much higher $\left(\tau=\sim 7\right.$ Newton $\left.\mathrm{m}^{-2}\right)$ than Jalangi ( $\tau=\sim 1$ Newton $\mathrm{m}^{-2}$ ) which ultimately make the river unstable and oscillating. $A$ flood is such an event that drastically modifies channel configuration especially channel width-depth. The control through dominant discharge operates as a negative feedback mechanism. However, peak discharges often cross the threshold limit of the fluvial system and transient form ratio (TFr), defined by the ratio between the relaxation time (tr) and the duration separating two successive disruptive events (td) (Brunsden and Thornes, 1979). When it becomes $>1$, it triggers positive feedback in the system.

Besides this magnitude frequency analysis of the discharge, another significant component of water discharge which triggers channel oscillation is the variability of discharge or unsteady flow characteristics. Variability stream discharge controls channel meandering by bar deformation, low-flow channel incision, and bend inception (Visconti et al., 2010). During our observation period (2005-2010) we found greater variability of stream discharge for Jalangi river at Mayapur gauge station (coefficient of variation $\sim 28 \%$ during August to October and $\sim 165 \%$ during January to December) than Bhagirathi at Katwa gauge station (CV $\sim 22 \%$ during August to October and $\sim 43 \%$ during January to December) due to purely variable monsoon spell. However, no corresponding increase in lateral erosion and bank failure through piping action (Hagerty $1991 \mathrm{a}, \mathrm{b}$ ) along the banks of Jalangi was observed because the water level required to reach the unconsolidated and non-cohesive sandy layer is very rarely met. We observed only 3 months of active flow (August to October) for Jalangi and during most of the period water level rises to $3 \mathrm{~m}$ from the bed while non-cohesive layers (coarse sandy layers) are mostly located above $3 \mathrm{~m}$. However, for Bhagirathi gauge rises well above the sandy layer to trigger erosion by slumping (Figure7). 

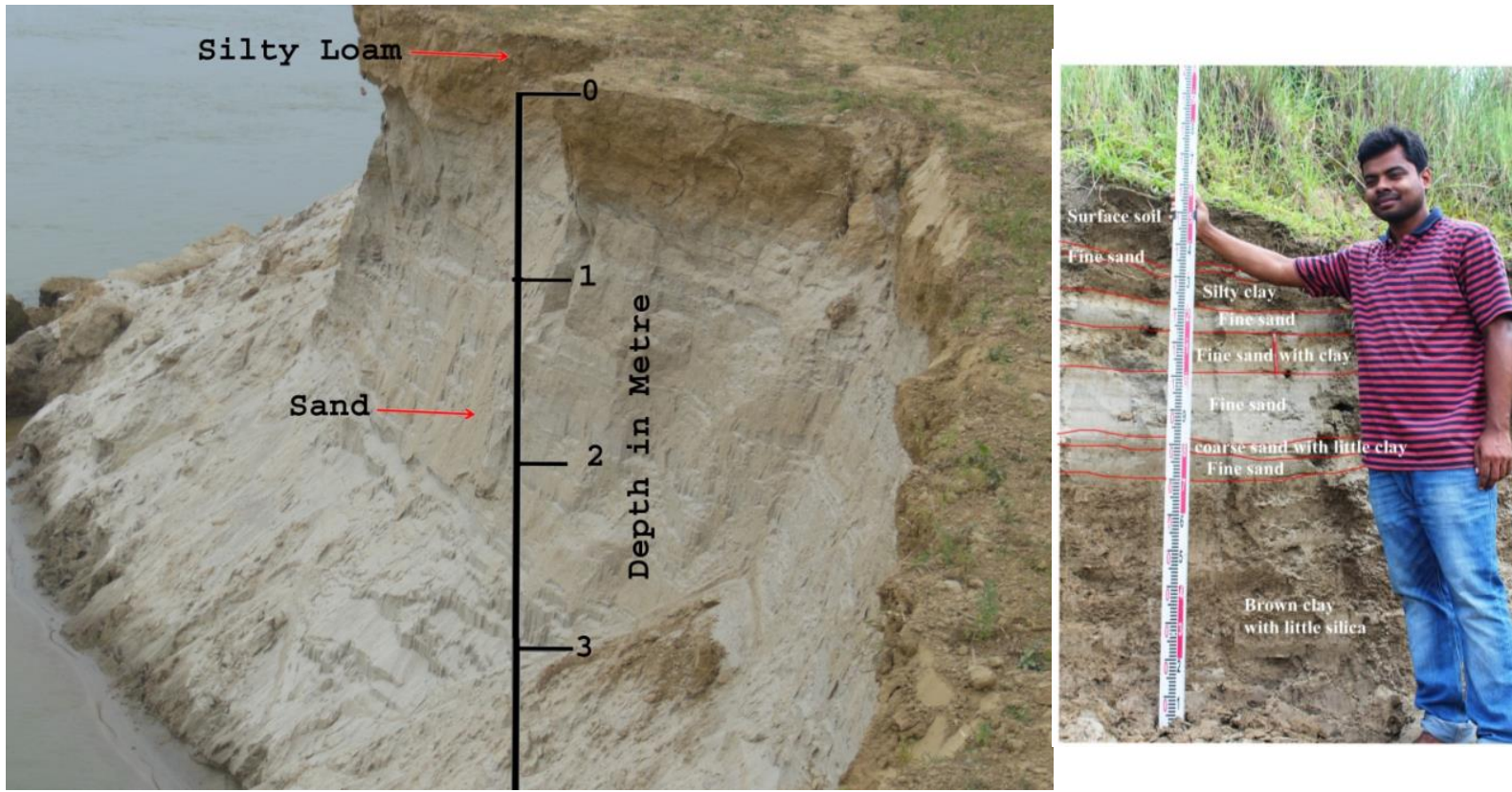

Figure 7. Bank material along the banks of a. river Bhagirathi in 2014 and b. Jalangi in 2018 (Source: Field photograph)

Again 'flow sequencing' (Rinaldi et al., 2008) plays an important role in channel instability. The nature of the river regime for Jalangi shows no discharge in the lean periods but river Bhagirathi depicts huge fluctuations even in the non-monsoon period (lean period) because of the contribution of water flow during January to May by the construction of Farakka barrage (Figure 8).

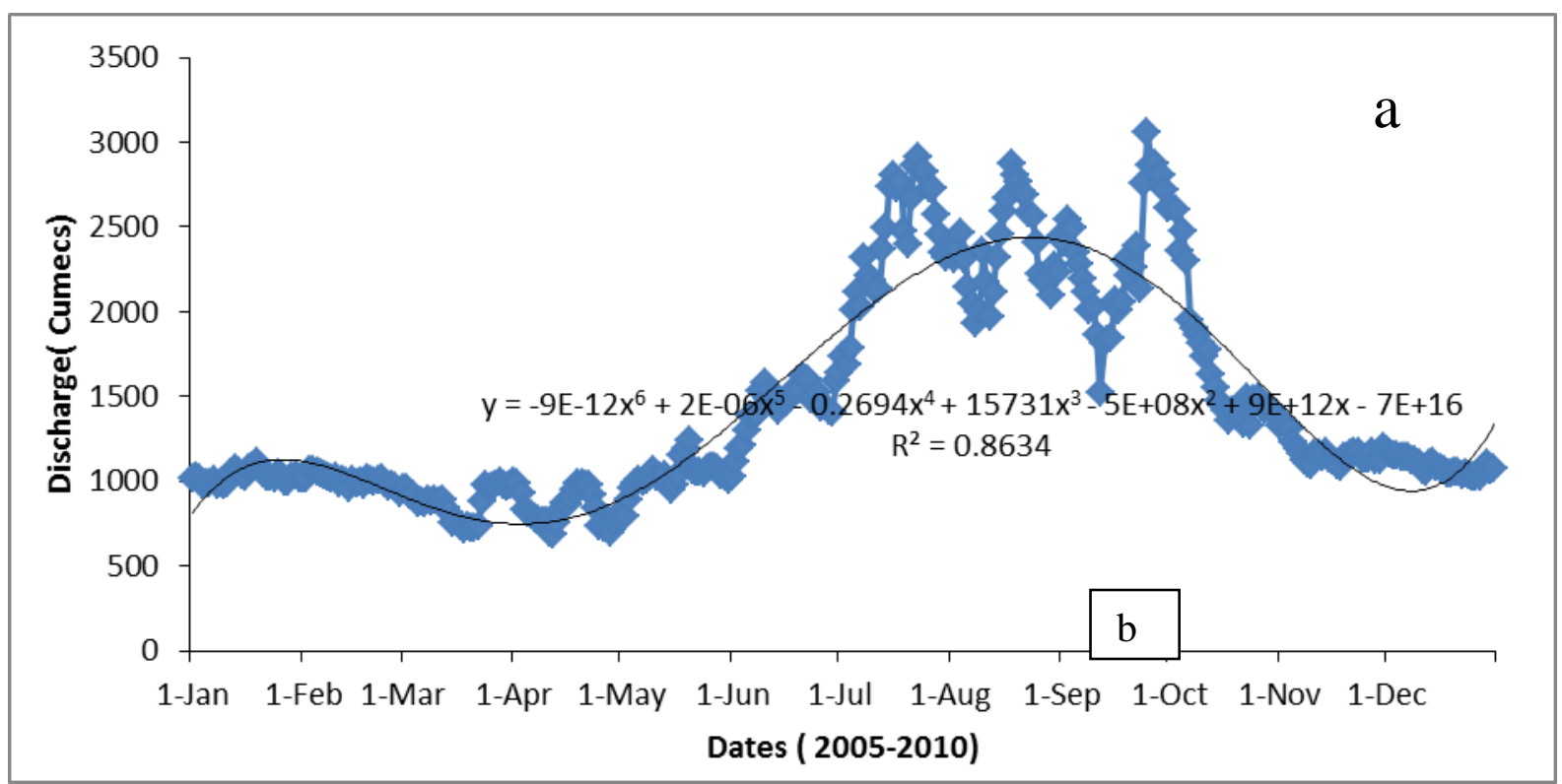




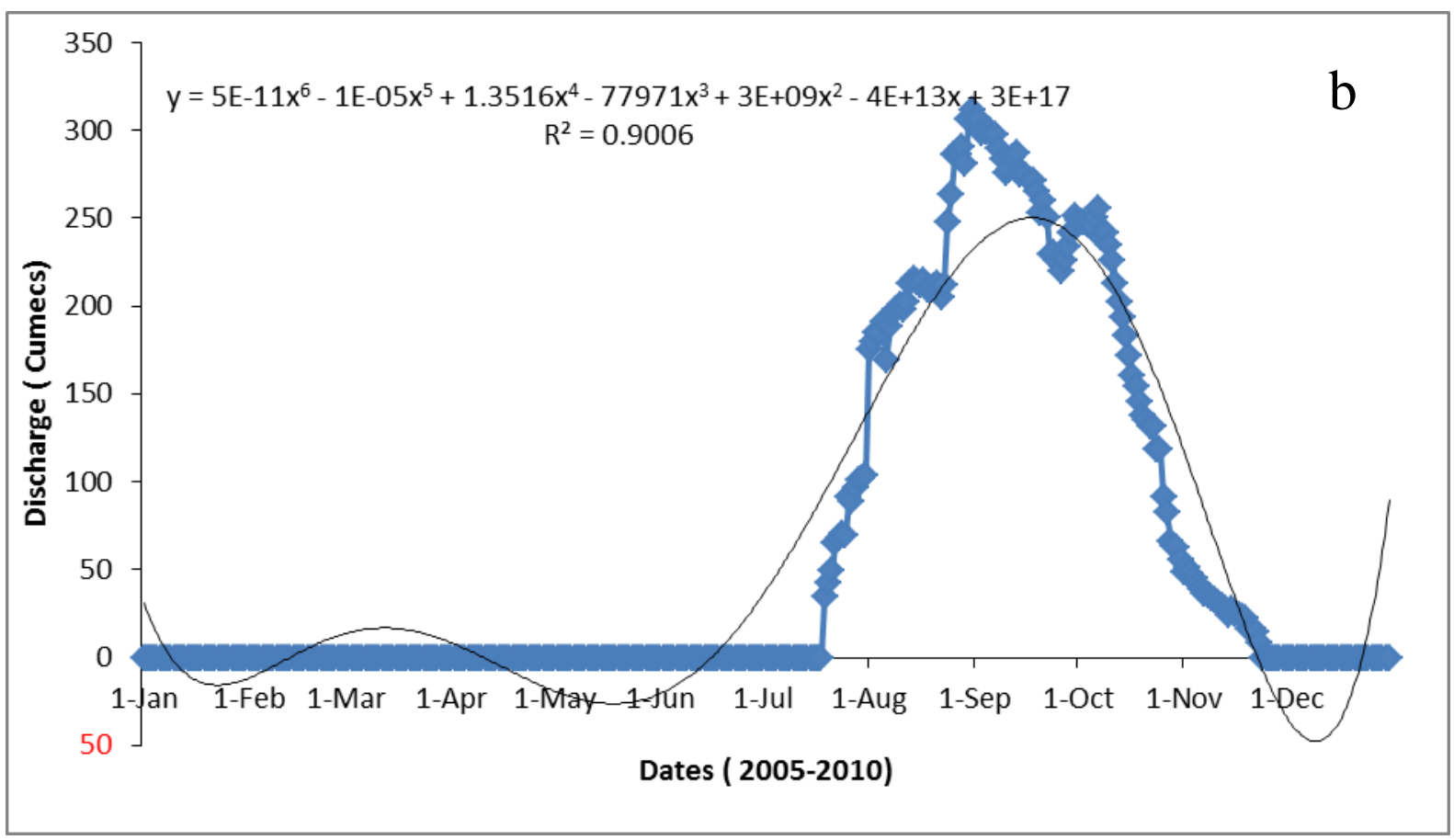

Figure 8. Annual Discharge hydrograph during 2005-2010; a. Bhagirathi at Katwa, b. Jalangi at Mayapur

The concept of flow competence has been used as the basis for analyzing streambed stability (Lorang and Hauer, 2003) and shear stress is generally accepted as a criterion for initiation of movement of bed materials (Petit, 1994) of a given size. It is also viewed that if the competence of the flow crosses the critical shear stress for entrainment of $D_{84}$ (Olsen et al., 1997) or $D_{90}$ (Petit, 1994) particle of bed materials, the stream bed become unstable which in turn induces instability in the stream channel. We observed RBS at Katwa and Swarupganj for Bhagirathi and at Swarupganj for Jalangi and tabulated below (Table 3).

It was found that RBS is much less for the river Bhagirathi (0.034 and 0.043$)$ than river Jalangi (0.064) and therefore bed as well banks of the river Bhagirathi is more unstable than that of river Jalangi. These differences in RBS also justify the variation in the meander belt width of the river Bhagirathi and the river Jalangi.

Table 3. Relative bed stability of Bhagirathi and Jalangi River

\begin{tabular}{|l|l|r|r|r|}
\hline \multicolumn{1}{|c|}{ River } & \multicolumn{1}{|c|}{ Station } & $\begin{array}{c}\text { Critical velocity for } \\
\text { entrainment } \\
\text { of D84 sediment } \\
\text { (m/sec) }\end{array}$ & $\begin{array}{r}\text { Bankfull Bed Velocity } \\
\text { (m/sec) }\end{array}$ & RBS \\
\hline Bhagirathi & Katwa & 0.03 & 0.88 & 0.034 \\
\hline Bhagirathi & Swarupganj & 0.03 & 0.47 & 0.043 \\
\hline Jalangi & Swarupganj & 0.03 & 0.064 \\
\hline
\end{tabular}

From the sedimentological perspective, it might be mentioned that river Bhagirathi carries higher suspended sediment concentration $(0.22 \mathrm{gm} . / \mathrm{lt}$. on the surface and 0.51 gm./lt. near bed at Swarupganj during 2009-2010) while Jalangi carries only 0.079 
gm./lt. on the surface and $0.13 \mathrm{gm} . / \mathrm{lt}$. near bed at Mayapur) which proves higher entrainment and scouring (Islam et al., 2001). Besides, Bhagirathi characterizes coarser D50 (e.g $0.191 \mathrm{~mm}$ at Swarupganj during monsoon in 2009-2010) compared to finegrained sediments of Jalangi ( 0.105 during the same period) because of the upland discharge and the contribution from the western plateau tributaries like Ajay, Mayurakshi (Guchhait et al., 2016). The D50 greatly controls the threshold limit of meandering or braiding channels (e.g. Millar, 2005). Though MacKenzie and Eaton (2017) showed that large immobile sediment load instead of surface and mobile D50 controls the channel morpho-dynamic characteristics and its stability, there is a consensus about the strong association between D50 and channel instability (Henderson, 1963). Coarser D50 creates higher particle Reynolds number for river Bhagirathi which makes channel geometry unstable and higher belt width.

\section{CONCLUSIONS}

In this present study, the meander belt of river Bhagirathi and river Jalangi is considered. The behavioural pattern of Bhagirathi- Hooghly is quite different from that of Jalangi. Bhagirathi-Hooghly is a saved channel by hydraulic control of the Farakka Barrage Project while Jalangi is a loser to nature. Naturally, river Bhagirathi-Hooghly is an active channel while Jalangi is almost a passive one the pulse of which is well portrayed in its meander belt width. Observing the pattern of the meander belt it can be mentioned that $\mathrm{MB}_{\mathrm{w1}}$ is almost equal in its magnitude for both Bhagirathi and Jalangi for 2004 and 2014. For $\mathrm{MB}_{w 2}$, belt width is higher for Jalangi than Bhagirathi for the relative straightening of the channel of Bhagirathi. But for the $\mathrm{MB}_{w 3}$ based on palaeo-channel study Bhagirathi crosses Jalangi. The final belt width i.e. based on a 100-year factor of safety shows that belt width is almost double for Bhagirathi (11.76 $\mathrm{km}$ ) than Jalangi $(6.64 \mathrm{~km})$. The higher and oscillating belt width is controlled by the fluvial architecture and hydraulics. The lithofacies depicted hard clay composition on the western margin of the delta which restricted the movement of Bhagirathi to a greater extent. However, the coarse sandy composition in the Bhagirathi-Jalangi interfluve and on the left bank of Jalangi fauoured huge channel oscillation for Bhagirathi and limited for Jalangi. It is due to differences in hydraulic forces depicted through higher discharge, higher steam power, higher shear stress, and lower relative bed stability coupled with higher suspended sediment concentration and D50 for Bhagirathi compared to Jalangi.

\section{REFERENCES}

Adedeji, O. H. (2011). Human settlement and development (ET 506). Abeokuta: Department of Environmental Management and Toxicology, UNAAB.

Bandyopadhyay, S. (1996). Location of Adi Ganga paleo channel, S. 24 Parganas, West Bengal. Geographical Review of India 58(2): 93-109.

Bandyopadhyay, S. (2007). Euolution of the Ganga Brahmaputra delta: A review. Geographical Review of India 6(9): 235-268. 
Basu, S. R. (1976). Fundamental problems of meander formation with special reference to Bhagirathi river. Indian J Power and River Valley Deu XVII(2): 15-23.

Basu, S. R., Ghosh, A., and S. K. De. (2005). Meandering and cut-off of the river Bhagirathi. In Kalwar, S. C., Sharma, M. L., Gurjar, R. D., Khandelwal, M. K. and S. K. Wadhawan. Geomorphology and environmental sustainability (pp20-37). Concept Publishing Company, New Delhi.

Beechie, T. J., Sear, D. A., Olden, J. D., Pess, G. R., Buffington, J. M., Moir, H., Roni, P., and M. M. Pollock (2010). Process-based principles for restoring river ecosystems. Bioscience 60(3): 209-222.

Bhattacharya, K. (2000). Bangladesher Nadnadi o Parikalpana. Kolkata: Vidyoday Library Private Ltd.

Biron, P. M., Buffin-Be'langer, T., Larocque, M., Chone', G., Cloutier, C., Ouellet, M., Demers, S., Olsen, T., Desjarlais, C., and J. Eyquem. (2014). Freedom space for rivers: a sustainable management approach to enhance river resilience. Environmental Management 54: 1056-1073.

Brauard, J. P., Amoros, C., Pautou, G., Bornette, G., Bournaud, M., Cha^ Telliers, M. C. D., Gibert, J., Peiry, J., Ois Perrin, J., and H. Tachet. (1997). River incision in southeast France: morphological phenomena and ecological effects. Regul Rivers: Res Manage 13: 75-90.

Bridge, J. S., and R. S. Tye. (2000). Interpreting the dimensions of ancient fluvial channel bars, channels, and channel belts from wireline-logs and cores. AAPG Bulletin 84(8): 1205-1228.

Brierley, G. J., and K. A. Fryirs. (eds) (2004). Geomorphology and river management: applications of the river styles framework. Malden: Blackwell Publishing.

Brunsden, D., and J. B. Thornes. (1979). Landscape sensitivity and change. Transactions of the Institute of British Geographers 4(4): 463-484.

Chitale, S. V. (2000). Future of the Kosi river and Kosi project. J. of Institution of Engineers(I) (81): 109-114.

Cygnia, F., and B. Timothy. (2003). A framework for delineating channel migration zones. Ecology Publication \#03-06-027. Washington State Department of Ecology.

Das, B. C. (2013). Changes and deterioration of the course of river Jalangi and its impact on the people living on its banks, Nadia, West Bengal, An Unpublished PhD Thesis. Kolkata: Calcutta University.

Ferguson, R. I. (1976). Disturbed periodic model for river meanders. Earth Surf. Process. Landforms 1(4): 337-347.

Gao, B. (1996). NDWI- A normalized difference water index for remote sensing of vegetation liquid water from space. Remote Sensing Environment 58: 257-268.

Gordon, N. D., McMahon, T., and B. L. Finlayson. (1992). Stream Hydrology: An Introduction for Ecologists. West Sussex, England: John Wiley and Sons. 
Guchhait, S. K., Islam, A., Ghosh, S., Das, B. C., and N. K. Maji. (2016). Role of hydrological regime and floodplain sediments in channel instability of the Bhagirathi river, Ganga-Brahmaputra delta, India. Physical Geography 37(6): 476510.

Hagerty, D. J. (1991a). Piping/sapping erosion. I. basic considerations. Journal of Hydraulic Engineering, 117(8): 991-1008.

Hagerty, D. J. (1991b). Piping/sapping erosion. II. basic considerations. Journal of Hydraulic Engineering, 117(8): 1009-1025.

Halder, J. (2018). Population change and land use dynamics: A case study of Paschim Medinipur District, West Bengal, India. European Journal of Geography 9(3): 23-44.

Henderson, F. M. (1963). Stability of alluvial channels. Transactions of the American Society of Civil Engineers, 128: 657-686.

Hirst, F. C. (1915). Reports on Nadia Rivers. Reprinted in River of Bengal (Vol. III 2002). Calcutta: Gazetteers Dept.

Hu, G. M., Ding, R. X., Li, Y. B., Shan, J. F., Yu, X. T., and W. Feng. (2017). Role of flood discharge in shaping stream geometry: Analysis of a small modern stream in the Uinta Basin, USA. Journal of Paleogeography 6(1):84-95.

Inglis, C. C. (1947). Meanders and their bearing on river training. Inst. Civ. Eng. (London), Mar. Waterways Eng. Div. Session 1946-47, Pap. No. 7, 3-54.

Islam, A. (2016). River bank erosion and its impact on economy and society: A study along the left bank of river Bhagirathi in Nadia District, West Bengal, unpublished PhD thesis. The University of Burdwan: India.

Islam, A., and S. K. Guchhait. (2017a). Analysing the influence of Farakka Barrage Project on channel dynamics and meander geometry of Bhagirathi river of West Bengal, India. Arab J Geosci 10(11): 245.

Islam, A., and S. K. Guchhait. (2017b). Search for social justice for the victims of erosion hazard along the banks of river Bhagirathi by hydraulic control: a case study of West Bengal, India. Environment, development and sustainability 19(2): 433-459.

Islam, M. R., Yamaguchi, Y., and K. Ogawa. (2001). Suspended sediment in the Ganges and Brahmaputra Rivers in Bangladesh: observation from TM and AVHRR data. Hydrological Processes 15(3): 493-509.

Jowett, I. G. (1989). River Hydraulic and Habitat Simulation, RHYHABSIM Computer Manual Vol. 6. Christchurch: New Zealand Fisheries Miscellaneous Report.

Julien, P. Y. (1985). Planform geometry of meandering alluvial channels. CER 84-85PYJ5.

Knighton, A. D. (1977). The meander problem. Geography 62(2): 106-111.

Kondolf, M. G. (2011). Setting goals in river restoration: when and where can the river "Heal itself"? In Simon, A., Bennett, S. J., and J. M. Castro, Stream restoration in dynamic fluvial systems: scientific approaches, analyses, and tools (Vol. 194, pp. 2943). Washington, DC: American Geophysical Union. 
Lane, E. W. (1955). The importance of fluvial morphology in hydraulic engineering. Proceedings, American Society of Civil Engineers 81: 745.

Langbein, W. B., and L. B. Leopold. (1966). River meanders-theory of minimum variance, Geological Survey Professional Paper 422-H.

Leopold, L.B., and M. G. Wolman. (1960). River meanders. Bull. Geol. Soc. Am. 71: 769794.

Lorang, M. S., and F. R. Hauer. (2003). Flow competence and streambed stability: an evaluation of technique and application. Journal of the North American Benthological Society 22(4): 475-491.

MacKenzie, L. G., and B. C. Eaton. (2017). Large grains matter: contrasting bed stability and morpho-dynamics during two nearly identical experiments. Earth Surface Processes and Landforms 42(8): 1287-1295.

Magdaleno, F., and J. A. Fernández-Yuste. (2011). Meander dynamics in a changing river corridor, Geomorphology 130: 197-207.

Mandal, S. (2017). Assessing the instability and shifting character of the river bank Ganga in Manikchak Diara of Malda District, West Bengal using Bank Erosion Hazard Index (BEHI), RS \& GIS. European Journal of Geography 8(4): 6-25.

Mazumder, S. K. (1993). Stability of river downstream of hydraulic structures. In Proceedings of the of VIII APD-IAHR Congress (Vol. 2, pp. 273-282).

Mazumder, S. K. (2004). Aggradation/degradation of Ganga near Farakka Barrage. Proc. Seminar on "Silting of Rivers- Problems and Solutions" org. by Min of Water Resources, Gout. of India, New Delhi Feb. 12-13.

McFeeters, S. K. (1996). The use of the Normalized Difference Water Index (NDWI) in the delineation of open water features. International journal of remote sensing 17(7): $1425-1432$.

Miall, A. D. (1977). A review of the braided-river depositional environment. EarthScience Reviews 13(1): 1-62.

Miall, A. D. (2006). The geology of fluvial deposits: sedimentary facies, basin analysis, and petroleum geology. 4th Corrected Printing. Verlag Berlin Heidelberg: Springer.

Millar, R. G. (2005). Theoretical regime equations for mobile gravel-bed rivers with stable banks. Geomorphology 64(3-4): 207-220.

Mukherjee, R. K. (1938). The Changing Face of Bengal. Calcutta: Calcutta University.

Ness, R. (2004). Belt width delineation procedures, Toronto and region conservation authority, Parish Geomorphic Ltd.

Olsen, D. S., Whitaker, A. C., and D. F. Potts. (1997). Assessing stream channel stability thresholds using flow competence estimates at bankfull stage. Journal of the American Water Resources Association 33(6):1197-1207.

Petit, F. (1994). Dimensionless critical shear stress evaluations from flume experiments using different gravel beds. Earth Surface Processes and Landforms 19: 565-576. 
Ray, A. (1999). Locational problems of the sixteenth century Bengal coast. Pratna Samiksha, Journal of the Directorate of Archaeology and Museum 6(8): 121-134.

Rennell, J. (1788). Memoir of a Map of Hindoostan or the Mogul Empire, Sec. 2, M. Brown, London.

Rinaldi, M., Mengoni, B., Luppi, L., Darby, S. E., and E. Mosselman. (2008). Numerical simulation of hydrodynamics and bank erosion in a river. Water Resources Research 44: W09428.

Roni, P., and T. Beechie. (eds.) (2012). Stream and watershed restoration: a guide to restoring riverine processes and habitats. Oxford, UK: Wiley-Blackwell.

Rudra, K. (2010). Banglar Nadikatha. Kolkata: Sahitya Samsad.

Rudra, K. (2011). The Encroaching Ganga and social conflicts: the case of West Bengal, India. Kolkata: http://www. gangawaterway. in/assets/02Rudra. Pdf

Sanyal, J., and X. X. Lu. (2006). GIS-based flood hazard mapping at different administrative scales: A case study in Gangetic West Bengal, India. Singapore Journal of Tropical Geography 27(2): 207-220.

Schumm, S. A. (1969). River metamorphosis. American Society of Civil Engineers, Journal of the Hydraulics Division, 95(1): 255-274.

Sen, H. (2010). The drying up of river Ganga: an issue of common concern to both India and Bangladesh. Current Science 99(6): 725-727.

Shahjahan, M. (1970). Factors controlling the geometry of fluvial meanders. International Association of Scientific Hydrology. Bulletin 15(3): 13-24.

Sherwill, W. S. (1858). Report on Rivers of Bengal. Calcutta: Calcutta Printing \& Publishing Co.

Shit, P. K., Bhunia, G. S. and R. Maiti. (2015). Farmers' perceptions of soil erosion and management strategies in South Bengal in India. European Journal of Geography 6(2): $85-100$.

Smith, K., and N. P. David. (2009). Environmental Hazards Assessing Risk and Reducing Disaster (5 ed.). London and Newyork: Rutledge publication.

Visconti, F., Camporeale, C., and L. Ridolfi. (2010). Role of discharge variability on pseudomeandering channel morphodynamics: Results from laboratory experiments. Journal of Geophysical Research: Earth Surface 115(F4).

VTANR (2004). River Corridor Delineation Process, Stream Geomorphic Assessment Handbooks. Vermont Agency of Natural Resources. 